\title{
Phytochemical Analysis of Local Spearmint (Mentha spicata) Leaves and Detection of the Antimicrobial Activity of its Oil
}

\author{
Abdel Moneim E. Sulieman*, Sitana E. Abdelrahman, Awad M. Abdel Rahim \\ Department of Food Science and Technology, Faculty of Engineering and Technology, University of Gezira, P. O. Box 20, \\ Wad-Medani, Sudan
}

\begin{abstract}
In the present study, the chemical composition of the spearmint leaves was determined as follows: moisture $(76.01 \pm 0.033) \%$, fiber $(2.1 \pm 0.03) \%$, ash $(3.48 \pm 0.001) \%$, protein $(1.75 \pm 01) \$.$% , fat (3.20 \pm 0.003) \%$, and carbohydrates $(14.46 \pm 0.15) \%$. On the other hand, the acid value, peroxide value, iodine value, free fatty acids, refractive index at $27 \mathrm{C}^{\circ}$ and density at room temperature were $0.0614,1.0,0.564,0.0305,1.4572$ and 0.8395 , respectively. The inhibitory effect of spearmint oil was detected for the growth of four microorganisms, including Escherichia Coli, Bacillus subtilis, Aspergillus niger and Candida albicans. The result indicated that the spearmint oil has a potent antimicrobial activity against all tested organisms, the highest antibacterial effect was against E.coli while the highest inhibitory level among all tested organisms was found against the mould Asperrgillus niger where the inhibition zone $(19 \mathrm{~mm})$ was at a higher oil concentration. The study pointed out the importance of spearmint and spearmint oil, as an antimicrobial, antiseptic and preservation agent.
\end{abstract}

Keywords Chemical Composition, Mineral, Antibacterial Activity

\section{Introduction}

Herbs are plant valued for their medicinal and aromatic properties and often grown and harvested for these unique properties. In most parts of the world, herbs are grown mainly as field crops or on small scale as catch crop among vegetables. The knowledge on herbs has been handed down from generation to generation thousand of years[1]. Herbs are used as natural source for treatment of various diseases. Also herbs are used for flavoring foods, culinary preparation, perfumery, cosmetics, beauty and body care. Many medicinal herbs are also food, oil and fiber plant[2].

Herbs are rich in volatile oil which gives pleasurable aroma. In addition, herbs may contain alkaloids and glycoside which have great pharmaceutical effect. Essential oils have been extensively investigated for their activity against a number of storage fungi, plant and human pathogens, bacteria, insect, pests and other harmful microorganisms. Almost all essential oil of herbs and spices (individual or combination) are highly inhibitory to selected pathogenic and spoilage microorganisms[3].

Spearmint is species of mint native to North Africa, Egypt and Morocco. It is an invasive species in Great Lakes region

* Corresponding author:

moneim_ug@yahoo.com (Abdel Moneim E. Sulieman)

Published online at http://journal.sapub.org/microbiology

Copyright (C) 2011 Scientific \& Academic Publishing. All Rights Reserved where it was first sighted in 1843. Spearmint has long tradition medicinal use. It was taken as a tea to treat general digestive problems. Spearmint is widely used in commercially manufactured product, cooking and medicine for its aromatic and flavorsome qualities[4]. The objectives of this study were to determine the chemical composition of the spearmint, to determine the physico-chemical properties of the spearmint oil, and to detect the antimicrobial activity of the spearmint oil.

\section{Materials and Methods}

\subsection{Spearmint Raw Material}

Fresh spearmint plant were obtained from Wad Medani local market (January, 2011), and was prepared for analysis by separating the leaves from the stems.

\section{Chemical Analysis}

The fresh spearmint leaves samples were analyzed for the contents of moisture, protein, fiber, ash and fat according to AOAC [5]. The total carbohydrates content was obtained as the difference between the sum of the other major ingredients, namely moisture, protein, fat. fiber and ash from 100 percent. The experiments were repeated three times and then the means and standard deviations were calculated.

\subsection{Mineral Determination}


Five grams from the spearmint samples was ignited at $600 \mathrm{C}$ over night then wetted using distilled water and transferred through a filter paper into a $100 \mathrm{ml}$ conical flask. $10 \mathrm{ml}$ of conc. $\mathrm{HCl}$ was added to the conical flask, and lastly the volume was completed using distilled water. For stock solution preparation, grams of metal salt was weighed and dissolved in one liter of distilled water to obtained 1000 PPM concentration. Stander solutions were prepared by taking difference volume from stock solution to $100 \mathrm{ml}$ conical flask and complete volume using distilled water. Then readings were taken and standard curve was formed.

Mineral content was calculated as follow:

$$
(\mathrm{Fe}, \mathrm{Na}, \mathrm{Ca} \text {, and } \mathrm{K}) \mathrm{mg}=\frac{\text { concentration } \times 100}{\text { sample } w t}
$$

\subsection{Spearmint Oil Extraction}

Distillation of spearmint oil was carried out using the method described by Harborne[6]. 75.7g of sample were weighed in $2000 \mathrm{ml}$ rounded bottom capacity flask. $1000 \mathrm{ml}$ distilled water was added and the clevenger receiver and condenser were attached to the top of flask. System was heated at $100{ }^{\circ} \mathrm{C}$ for 4 hours till the volume of oil at the top of the receiver became constant. Oil was pipetted and dried over sodium sulphate anhydrous and stored in dark container in refrigerator till used.

\subsection{Physicochemical Properties of Spearmint Oil}

The physicochemical properties of spearmint oil were determined according to the AOCS[7] methods. These properties included: the acid value $\%$, Peroxide value, iodine value, the free fatty acid, refractive index and density at room temperature.

\subsection{Testing of Spearmint Oil for Antibacterial Activity}

The distilled spearmint oil was dissolved in methanol. Three different oil concentrations were prepared 5\%, 10\% and $20 \%$. All oil concentrations were tested against standard organisms which include: two gram - negative organisms (Escherichia coli ATCC 25922), (Bacillus subtilis NCTC 8236), two fungi (Aspergillus niger ATCC 9763) and (Candida albicans ATCC 7596).

The cup-plate agar diffusion method was adopted with some minor modification to assess the antibacterial activity of the prepared extract. Twoml of the standardized bacteria stock suspension contains $\left(10^{8}-10^{9}\right)$ colony forming units perml (CFU), were thoroughly mixed with $200 \mathrm{ml}$ of sterile molten nutrient agar, which was maintained at $45^{\circ} \mathrm{C}$.

Twentyml aliquots of the inoculated agar were distributed into sterile Petri dishes. The agar was left to set and each of these plates $(10 \mathrm{~mm}$ in diameter) were cut using a sterile cork borer number 4 , and the agar discs were removed. Alternate cups were filled with $0.1 \mathrm{ml}$ sample of each of the extracts using adjustable pipette, and allowed to diffuse at room temperature for two hours. The plates were then incubated in the upright position at $37^{\circ} \mathrm{C}$ for 10 hours. Two replicates were carried out for extract against each of the tested or- ganism.

After incubation, the diameter of the resultant growth inhibition zones was measured, averaged and the mean values were calculated. The result was interpreted in terms of the commonly used terms (sensitive) and (resistance).

For antifungal activity, the same method for bacteria described by Kavanagh (1972) was adopted using sabouraud dextrose agar instead of nutrient agar.

\section{Results and Discussion}

\subsection{Chemical Composition}

The proximate chemical composition of the fresh spearmint leaves is shown in Table (1). The moisture content of spearmint was found to be $76.01 \pm 0.03 \%$ which was a greater than that of the United States Government Specification which is $73 \%$ and less than ( $80 \%$ ) according to the Canadian Government Specifications for Spearmint[8].

The crude fiber content of fresh spearmint leaves was found to be $6.2 \%$, and this value complied with fiber content of spearmint $(6.8 \%)$ as determined by the United States Drug Administration[9] .

The ash content of the fresh spearmint leaves was found to be $(3.48 \%)$, which was greater than $(0.29 \%)$ specified by the Canadian Government Standard Specification for Spear$\operatorname{mint}[8]$.

Table 1. Chemical composition (\%) of the fresh spearmint leaves

\begin{tabular}{|c|c|}
\hline Parameter & Value \\
\hline Moisture (\%) & $76.01 \pm 0.033$ \\
\hline Ash (\%) & $3.48 \pm 0.001$ \\
\hline Protein\% $\%$ & $1.75 \pm 0.1$ \\
\hline Fat\% & $2.20 \pm 0.003$ \\
\hline Fiber\% & $6.2 \pm 0.03$ \\
\hline Carbohydrates\% & $10.39 \pm 0.15$ \\
\hline $\mathrm{Na}(\mathrm{mg} / 100 \mathrm{~g})$ & 7.2 \\
\hline $\mathrm{Ca}(\mathrm{mg} / 100 \mathrm{~g})$ & 13 \\
\hline $\mathrm{K}(\mathrm{mg} / 100 \mathrm{~g})$ & 24 \\
\hline $\mathrm{Fe}(\mathrm{mg} / 100 \mathrm{~g})$ & 2.5 \\
\hline
\end{tabular}

The fresh spearmint leaves was found to contain $1.75 \%$ protein, which was less than (3.75\%) reported by USDA[9] for spearmint, and less than those of peppermint and basil which were $3.75 \%$ and $3.15 \%$, respectively, [10].

Fat content of the fresh spearmint leaves was found to be $(2.203 \%)$ which is relatively more than the value $1.18 \%$ reported by USDA[9] , and also more than that of pepper$\operatorname{mint}(1.94 \%)$ and basil $(0.64 \%)[10]$.

Spearmint leaves was found to contain $10.39 \%$ carbohydrates, and this value is relatively less than the value $14.89 \%[9]$.

The spearmint leaves was found to contain $7.2 \mathrm{mg}$ of sodium which was higher than $(3.4 \mathrm{mg})$ according to USDA[9]. Also, it contains $13 \mathrm{mg}$ of calcium which was less than the value $22.49 \mathrm{mg}$ determined by the USDA[9], and it contains 
$2.5 \mathrm{mg}$ of iron which was higher than $1.3 \mathrm{mg}$ as prescribed by the USDA[9]. The fresh spearmint was found to contain $24 \mathrm{mg}$ of potassium which was less than $31.5 \mathrm{mg}$ potassium according to the USDA[9]

\subsection{Physico-chemical Properties of Spearmint Oil}

The physico-chemical properties of spearmint were shown in Table (2). The acid value of the spearmint oil was found to be $(0.0610 \mathrm{mg} \mathrm{KOH} / \mathrm{g}$ of oil) which was less than $(0.6 \mathrm{mg} / \mathrm{g}$ oil ) of cotton seed oil, and (10mg /g oil) of sesame oil according to the Codex Alimentarius Standards[11].

The iodine value of the spearmint oil is $(0.5467 \mathrm{mg} \mathrm{I} / \mathrm{g}$ oil $)$. The iodine value (the weight of iodine absorbed by 100 parts by weight of fat, the higher iodine value, the greater ability of oil or fat to become rancid). The peroxide value of the spearmint oil was found to be $(1 \mathrm{~m}$. Eq.Oxgen $/ \mathrm{kg}$ oil) which was less than that of sesame oil (10 m.Eq. Oxgen $/ \mathrm{kg}$ of oil), and the cotton seed oil (4 m.Eq. Oxgen $/ \mathrm{kg}$ oil) according to Codex Alimentarius Standrds[11]. The free fatty acid of spearmint leaves oil was found to be $0.0305 \%$.

The refractive index of the spearmint oil was found to be 1.4772 at $27^{\circ} \mathrm{C}$, which is in the range of refraction number $\left(1.4820\right.$ and 1.4900 at $\left.27 \mathrm{C}^{\circ}\right)$ as stated by Canadian Government Specification[8]. The density of the spearmint oil was found to be 0.8395 at room temperature, which is less than the range of density ( 0.920 and 0.937 at room temp) as stated by Canadian Government Specification[8].

Table 2. Physico- chemical properties of spearmint oil

\begin{tabular}{|c|c|}
\hline Parameter & Value \\
\hline Acid value Mg KOH/g of oil & 0.0614 \\
\hline Iodine value Mg I/g oil & 1 \\
\hline Peroxide value M.Eq oxgen $/ \mathrm{kg}$ oil & 0.564 \\
\hline Free fatty acid (oleic acid) $100 \mathrm{mg}$ oil & $0.0305 \%$ \\
\hline Refractive index (at $27^{\circ} \mathrm{C}$ ). & 1.4572 \\
\hline Density (at room temperature). & 0.8395 \\
\hline
\end{tabular}

\subsection{Antimicrobial Activity of Spearmint Oil}

The average of the diameters of the growth inhibition zones is shown in Tables (3) and (4). The results indicated that spearmint oil has apparent antimicrobial activity against tested organisms.

The spearmint oil showed potent antibacterial activity against Escherichia coli, where the inhibition zones were $17 \mathrm{~mm}, 15 \mathrm{~mm}$ at the higher and the lower concentration, respectively. This result agreed with Lixandru, et al.,[12] who stated that spearmint oil exhibited considerable inhibition capacity against $E$ coli. This result was also complied with Nakatani and Nobuji.,[13], who stated that, the spearmint oil has potent antibacterial activity against $E$ coli.

The spearmint oils showed antibacterial activity against Bacillus subtilis i.e. the inhibition zone $(16 \mathrm{~mm})$ and $(14 \mathrm{~mm})$ at higher and lower concentration respectively. This result complied with Elumalia and Krishna[14], who reported that, the spearmint oil was proved as a good antibacterial activity against Bacillus subtilis.

The spearmint oil exhibited excellent antifungal activity against Candida albicans when the inhibition zone $18 \mathrm{~mm}$ and $14 \mathrm{~mm}$ at higher and lower concentrations, respectively, also, the spearmint oil showed antifungal activity against Aspergillus niger with inhibition zone reached $(19 \mathrm{~mm})$ at high concentration, and $(15 \mathrm{~mm})$ at low concentration. The result was complied with what was stated by Lixadru, et $a l$,[12] stated that the essential oil of spearmint and other plant such as thyme, basil, coriander, rosemary, sag, fennel, and caraway, were investigated against three fungal strains which belong to the species reported to be involved in food poisoning and/or food decay: Candida albicans, Aspergillus niger and penicillium spp. They found that thyme and spearmint oils better inhibited the fungal species.

Table 3. The antibacterial property of different concentrations of the extract against standard organisms (E. coli and Bacillus subtilis)

\begin{tabular}{|c|cc|}
\hline Oil concentration & \multicolumn{2}{|c|}{ Inhibition Zone Diameter(mm) } \\
& E.c & $B . s$ \\
\hline $20 \%$ & 17 & 16 \\
\hline $10 \%$ & 17 & 15 \\
\hline $5 \%$ & 15 & 14 \\
\hline
\end{tabular}

E.c: Escherichia coli

B.s : Bacillus subtilis

$>15 \mathrm{~mm}$ : sensitive, $14-15$ Intermediate, $<14 \mathrm{~mm}$ : resistance

Table 4. The antifungal activity of different concentrations of the extract against standard organisms (Aspergillus niger and Candida albicans)

\begin{tabular}{|c|cc|}
\hline Oil concentration & \multicolumn{2}{|c|}{ Inhibition Zone diameter (mm) } \\
& As.n & C.a \\
\hline $20 \%$ & 19 & 18 \\
\hline $10 \%$ & 17 & 17 \\
\hline $5 \%$ & 15 & 14 \\
\hline
\end{tabular}

As.n : Aspergillus niger

C.a : Candida albicansrm

$>15 \mathrm{~mm}$ : sensitive, $14-15$ Intermediate, $<14 \mathrm{~mm}$ : resistance

\section{Conclusions}

Spearmint is a popular herb. It has been used to impart flavor, food preservation, and as a tradition medicine. The study indicated that spearmint and spearmint oil can be used as antibacterial, antifungal and antiseptic, so that they can be used in food perseveration. More studies are needed to determine the antimicrobial activity of spearmint and spearmint oil on other organisms which cause food spoilage, poisoning and food borne diseases.

\section{ACKNOWLEDGEMENTS}

Our sincere regard to the members of the Department of Food Science and Technology, Faculty of Engineering and Technology, University of Gezira for their helps during this study.

\section{REFERENCES}

[1] Brown, D. (1995). The Royal Horticulture Society- Enclo- 
pedia of Herb and their uses. Dorling Kindersley limited London

[2] Peter K. V. (2001). Hand book of Herb and Spices. Wood head publishing limited, Abington

[3] Kalemba, D. and Kunicka, A. (2003) . Antibacterial and antifungal properties of essentials oils. Curr Med Chem.; May, 10 (10): 813-839

[4] http://www.mountainroseherbs.com/spearmint.php, 2010)

[5] AOAC (2000). Official Methods of Analysis (17th Ed.). Association Of Official Analytical Chemists, Arlington,VA. USA

[6] Harborne, J. B. (1984). Phyto-chemical Methods. $2^{\text {nd }}$ edition. Chapman and Hall

[7] A.O.C.S (1981). Official tentative Methods of Analysis. $3^{\text {rd }}$ edition

[8] Candian Government Specification for Spearmint (1964). From Depatment of National Health and Welfare, Canada. Food and drug Regulation
[9] USDA (1977). United State Drug Administration Composition of food and herbs USDA Agriculture hand book 8-2 January 1977

[10] March, A. C. Moss; M.K. and Murphy, E. W. (1977). Composition of foods, herb and spices, raw material. Processed. Prepared. Washington, Dc: USDA Agric. Res. Serve. Agric. HandbookNo.8-2

[11] CODEX Alimentarius Standers for fats, oils, and related products, volume 8, FAO, 1993

[12] Lixandru, B.; Dracea, N.; Dragomirescu, E.; Coldea, I.; Dobre, E. and Rovinaru, C. (2010). Antimicrobial activity of plant essential oil against bacteria and fungal species involving in food poisoning. Cantacuzino "National Institute of Research-Development of Microbiology and Immunology, Bucharest, Romania

[13] Nakatani, and Nobuji, (1994). Antioxidant and Antimicrobial Constituents of herb and spices.Spices, herbs and edible fugi. Elsevies B.V.,251-271

[14] Elumalai, K. and Krishnappa, K. (2008). Antibacteria activity of six essential oils against some pathogenic bacteria. Food Protect 17(9):1854 